\title{
COMPARISON OF MIDAZOLAM AND MINI DOSE SUCCINYLCHOLINE IN AIDING LMA INSERTION IN ADULT ELECTIVE SURGERY PATIENTS - A RANDOMISED CLINICAL TRIAL IN GVMC
}

\author{
Rajamani Jayadharmarajan Balamurugan'1, Iswaran Chandra Thendral Arasu²
}

${ }^{1}$ Senior Assistant Professor, Department of Anaesthesiology, Government Vellore Medical College Hospital, Adukkamparai, Vellore. ${ }^{2}$ Assistant Professor, Department of Anaesthesiology, Government Vellore Medical College Hospital, Adukkamparai, Vellore.

ABSTRACT

\section{BACKGROUND}

The LMA ${ }^{1}$ has gained widespread acceptance as general purpose airway and is used in up to $30 \%$ of patients undergoing general anaesthesia. 2,3 The most popular induction agent for LMA insertion continues to be propofol as it obtunds oropharyngeal reflexes. $4,5,6$

\section{MATERIALS AND METHODS}

1. All patients were randomly grouped under 2 groups viz., Group A propofol with midazolam, Group B propofol with succinylcholine. Group A received $0.04 \mathrm{mg} / \mathrm{kg}$ body weight of midazolam.

2. All patients are pre oxygenated with $100 \% \mathrm{O}_{2}$ for $3 \mathrm{~min}$. All patients are then induced with propofol bolus until the endpoint of loss of eye lash reflex is obtained. Then, in group B alone $0.1 \mathrm{mg} / \mathrm{kg}$ succinylcholine is injected. We wait for 60 sec. for fasciculations if any and proceed with LMA. Insertion. Patients were then maintained on assisted ventilation with $100 \%$ oxygen over a period of $60 \mathrm{sec}$. After $60 \mathrm{sec}$., well-lubricated LMA was inserted by the standard techniques. During insertion of laryngeal mask airway, jaw relaxation, gagging/coughing, limb movements, presence or absence of laryngospasm, haemodynamics were noted. If jaw relaxation was found to be inadequate to permit LMA insertion, boluses of propofol were given until adequate jaw relaxation occurred.

\section{RESULTS}

In this study, the conditions of LMA insertion, patient's response to LMA insertion and the haemodynamic changes ${ }^{7,5,6}$ during and after LMA insertion ${ }^{8}$ in the following two groups of patients were observed.

Group A - Inj. Propofol $2.5 \mathrm{mg} / \mathrm{kg}+0.04 \mathrm{mg} / \mathrm{kg}$ midazolam.

Group B - Inj. Propofol $2.5 \mathrm{mg} / \mathrm{kg}+0.1 \mathrm{mg} / \mathrm{kg}$ succinylcholine.

Good jaw relaxation, good overall insertion conditions, first attempt insertion, no airway trauma, no increased dose of propofol, stable haemodynamics were noticed in group A patients.

\section{CONCLUSION}

To conclude, addition of Midazolam (0.04 mg/kg) to the standard dose of propofol provides better LMA insertion conditions than the addition of mini dose Succinylcholine $(0.1 \mathrm{mg} / \mathrm{kg})$.

\section{KEYWORDS}

Midazolam, Propofol, Succinylcholine.

HOW TO CITE THIS ARTICLE: Balamurugan RJ, Arasu ICT. Comparison of midazolam and mini dose succinylcholine in aiding LMA insertion in adult elective surgery patients - A randomised clinical trial in GVMC. J. Evolution Med. Dent. Sci. 2016;5(99):72347240, DOI: $10.14260 / \mathrm{Jemds} / 2016 / 1637$

\section{BACKGROUND}

The LMA has gained widespread acceptance as general purpose airway 9,10 over conventional face mask and ET tube and is used in up to $30 \%$ of patients undergoing general anaesthesia. $^{3}$

The most popular induction agent for LMA insertion continues to be propofol induction agent as it obtunds oropharyngeal reflexes. ${ }^{4}$ Standard induction doses (2-3 $\mathrm{mg} / \mathrm{kg}$ ) of propofol, which allow adequate jaw relaxation

Financial or Other, Competing Interest: None.

Submission 04-11-2016, Peer Review 27-11-2016,

Acceptance 05-12-2016, Published 12-12-2016.

Corresponding Author:

Rajamani Jayadharmarajan Balamurugan,

Senior Assistant Professor,

Department of Anaesthesiology,

Government Vellore Medical College Hospital,

Adukkamparai, Vellore-632011.

E-mail:balamuragan75@gmail.com

DOI: $10.14260 /$ jemds/2016/1637

and prevent patient reaction to LMA insetion ${ }^{4,11}$ i.e., gagging, coughing, movements etc., commonly result in hypotension. ${ }^{12,13}$

A prospective randomised controlled study was constructed to compare the usefulness of midazolam and mini dose succinylcholine ${ }^{14,15}$ to aid LMA insertion in propofol anaesthesia, in patients coming for elective short general surgery procedures.

The study was conducted in Department of Anaesthesiology, Government Vellore Medical College.
Aim of the Study
The aim of the study is to observe the usefulness of Midazolam and mini dose Succinylcholine to facilitate the insertion of laryngeal mask airway during propofol anaesthesia in elective general surgery patients based on the following parameters.
- Conditions during insertion of laryngeal mask airway such as jaw relaxation, ease of insertion, number of 
attempts for insertion, airway trauma and total dose of propofol.

- Patient's response to insertion of laryngeal mark airway such as gagging, coughing, head and limb movements, laryngospasm, etc.

- Haemodynamic parameters like mean arterial pressure, heart rate and oxygen saturation.

\section{MATERIALS AND METHODS}

After obtaining institutional ethical committee clearance and the patient consent, the study was carried out on 50 patients posted for elective surgical procedures lasting less than or equal to $45 \mathrm{~min}$. at Government Vellore Medical College.

Patient belonging to the age group of 18-50 years of both the sexes were selected.

\section{Inclusion Criteria}

- Elective short surgical procedures lasting less than or equal to 45 min. patients of ASA physical status I and II.

- Aged between 18 - 50 years of both sexes.

\section{Exclusion Criteria}

- Patients with full stomach, pregnant patient.

- Patients posted for emergency surgery.

- Patients with oral, perioral pathology such as tumours, abscess or grossly enlarged tonsils.

- Patients with fixed reduced pulmonary compliance such as pulmonary fibrosis, severe cardiovascular, hepatic or renal disease.

\section{Types of Surgeries}

The various types of surface surgeries that were included in this study are shown in Table 1.

\begin{tabular}{|c|c|c|c|}
\hline Types of Surgeries & $\begin{array}{c}\text { Group } \\
\text { A }\end{array}$ & $\begin{array}{c}\text { Group } \\
\text { B }\end{array}$ & Total \\
\hline Fibroadenoma Excision & 5 & 8 & 13 \\
\hline Lipoma Excision & 4 & 3 & 7 \\
\hline $\begin{array}{c}\text { Hydrocoele - Excision and } \\
\text { Eversion }\end{array}$ & 2 & 3 & 5 \\
\hline Herniorrhaphy & 2 & 2 & 4 \\
\hline Ganglion Excision & 2 & 1 & 3 \\
\hline $\begin{array}{c}\text { Gynaecomastia - Webster's } \\
\text { Procedure }\end{array}$ & 1 & 1 & 2 \\
\hline Haemorrhoids, fissure in ano & 3 & 3 & 6 \\
\hline Other minor surgeries & 6 & 4 & 10 \\
\hline \multicolumn{2}{|c|}{ Table 1 } & \\
\hline
\end{tabular}

\section{Patient Preparation}

All patients were advised overnight fasting.

\section{Pre-Loading}

All patients are preloaded with $10 \mathrm{~mL} / \mathrm{kg}$ of balanced salt solution.

\section{Pre-Medication}

All patients were premedicated with

Inj: Glycopyrrolate $4 \mathrm{mcg} / \mathrm{kg}$ IV.

Inj: Fentanyl ${ }^{17} 2 \mathrm{mcg} / \mathrm{kg}$.

\section{Monitors Used}

Noninvasive Blood pressure (NIBP), Electrocardiogram (ECG), Pulse oximetry, $\mathrm{ETCO}_{2}$

\section{Methodology}

All patients were randomly grouped under 2 groups viz., Group A propofol with midazolam, Group B propofol with succinylcholine. Group A received $0.04 \mathrm{mg} / \mathrm{kg}$ body weight of midazolam.

All patients are preoxygenated with $100 \% \mathrm{O}_{2}$ for $3 \mathrm{~min}$. All patients are then induced with propofol bolus until the endpoint of loss of eye lash reflex is obtained. Then in group B alone $0.1 \mathrm{mg} / \mathrm{kg}$ succinylcholine ${ }^{16,14,15}$ is injected. We wait for $60 \mathrm{sec}$. for fasciculations if any and proceed with LMA insertion. Patients were then maintained on assisted ventilation with $100 \%$ oxygen over a period of $60 \mathrm{sec}$. After 60 sec., well-lubricated LMA was inserted by the standard techniques described in the intravent manual. During insertion of laryngeal mask airway jaw relaxation, gagging/coughing, heads \& limb movements, presence or absence of laryngospasm were noted. If jaw relaxation was found to be inadequate to permit LMA insertion, boluses of propofol were given until adequate jaw relaxation occurred.

\section{Jaw Relaxation}

Was graded by Young, Clark, Dundee.

Adequate - Adequate jaw relaxation and LMA insertion done without any difficulty.

Incomplete - Inadequate jaw relaxation but LMA insertion is possible with difficulty.

Poor - Inadequate jaw relaxation and LMA insertion is not possible.

\section{Overall Insertion Conditions}

Was graded by Lund and Stovner.

Excellent - (Insertion - easy, no reaction from the patient).

Good - (Insertion results in slight cough or movements).

Poor - (Insertion possible but with marked unacceptable response).

\section{Gagging or Coughing on Insertion}

Was graded as present or absent.

\section{Head and Limb Movements}

Was graded as present or absent.

After insertion of LMA, cuff was inflated with appropriate volume of air and connected to the breathing circuit. Correct positioning of the LMA was verified by bilateral chest expansion, bilateral air entry by auscultation, capnography and the absence of leak around the cuff. The ventilation was assisted with bag until resumption of spontaneous respiration. Anaesthesia was maintained with oxygen (2 L/min.), Nitrous oxide (4 L/min.) and Halothane (1\%). The haemodynamics were monitored before premedication, 1 minute after LMA insertion and throughout till agents were discontinued and $100 \%$ oxygen administered. LMA was removed after the patient had gained adequate level of consciousness and after adequate return of pharyngeal reflexes. After removal of LMA, the patient was observed for any spasm, coughing, vomiting. In the postoperative period, the patients were observed in the ward for 24 hours. 


\section{Statistical Analysis Using Student T-Test}

The t-test assesses whether the means of two groups are statistically different from each other. The $t$-value will be positive if the first mean is larger than the second and negative if it is smaller. Once we compute the $t$-value we look it up in a table of significance to test whether the ratio is large enough to say that the difference between the groups is not likely to be a chance finding.

\section{RESULTS}

This study was conducted and 50 patients were divided into 2 groups of 25 patients each.

Group A - Propofol with midazolam group.

Group B - Propofol with Succinylcholine.

\section{Demographic Profile}

In group B, $48 \%$ of patients are male and rest $53 \%$ are female, while in group A $52 \%$ of patients are male and rest female. The mean age of patient is 30.12 and 30.84 in groups $A$ and $B$ respectively. The mean weight is 53 and 53.22 in groups A and B respectively. Patients in each were statistically comparable in relation to sex, age and weight. See Fig -1 .

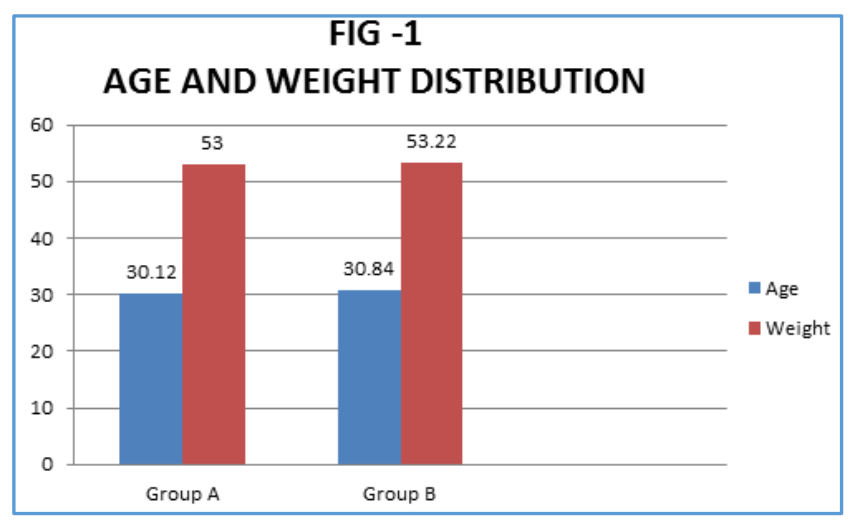

Comparison of Conditions for LMA Insertion
Jaw relaxation, overall insertion conditions and number of attempts for LMA insertion were observed and the results were tabulated as follows. Also see figure 2 .

\begin{tabular}{|c|c|c|}
\hline Jaw Relaxation & Group A & Group B \\
\hline Adequate & 25 & 16 \\
\hline Incomplete & 0 & 9 \\
\hline Poor & 0 & 0 \\
\hline \multicolumn{2}{|c|}{ Table 2 } \\
\hline
\end{tabular}

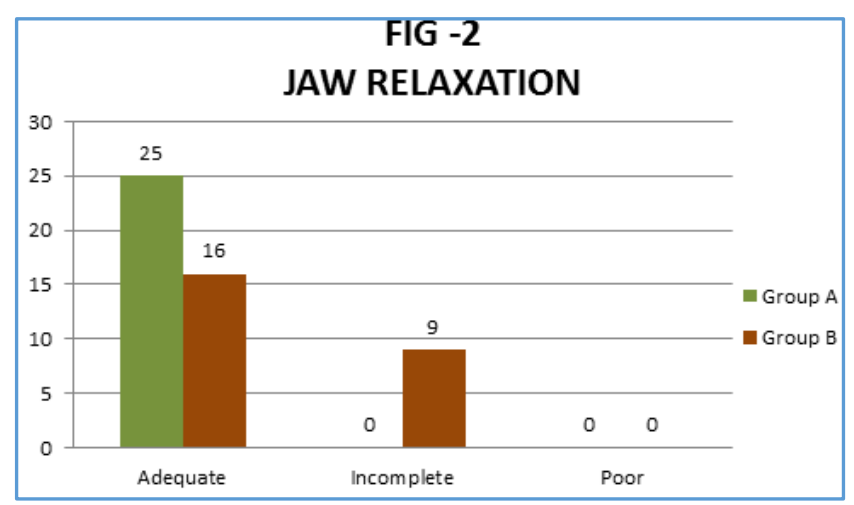

\section{One-Sample Statistics}

\begin{tabular}{|c|c|c|c|c|}
\hline & N & Mean & $\begin{array}{c}\text { Std. } \\
\text { Deviation }\end{array}$ & $\begin{array}{c}\text { Std. Error } \\
\text { Mean }\end{array}$ \\
\hline Adequate & 3 & 16.33 & 8.505 & 4.910 \\
\hline Incomplete & 3 & 8.67 & 8.505 & 4.910 \\
\hline \multicolumn{5}{|c|}{ Table 3 } \\
\hline
\end{tabular}

\section{One-Sample Test}

\begin{tabular}{|c|c|c|c|c|c|c|}
\hline \multirow{2}{*}{} & \multicolumn{3}{|c|}{ Test Value =0 } \\
\cline { 2 - 7 } & \multirow{2}{*}{$\mathbf{t}$} & \multirow{2}{*}{ Df } & \multirow{2}{*}{ Sig (2-tailed) } & \multirow{2}{*}{ Mean Difference } & \multicolumn{2}{|c|}{ 95\% Confidence Interval of the Difference } \\
\cline { 3 - 7 } & & & & Lower & Upper \\
\hline Adequate & 3.326 & 2 & .080 & 16.333 & -4.79 & 37.46 \\
\hline Incomplete & 1.765 & 2 & .220 & 8.667 & -12.46 & 29.79 \\
\hline \multicolumn{7}{|c|}{ Table 4 } \\
\hline
\end{tabular}

Jaw relaxation was more in group A compared to group B and the results are statistically as shown in tables above.

\section{Overall Ease of Insertion}

The overall ease of insertion is graded as excellent, good, poor or unacceptable. The overall ease of insertion was excellent in $100 \%$ of group A patients, while it was $44 \%$ in group B. See Fig . 3 \& Table 5.

\begin{tabular}{|c|c|c|}
\hline Ease of Insertion & Group A & Group B \\
\hline Excellent & 25 & 11 \\
\hline Good & 0 & 14 \\
\hline Poor & 0 & 0 \\
\hline \multicolumn{2}{|c|}{ Table 5 } \\
\hline
\end{tabular}




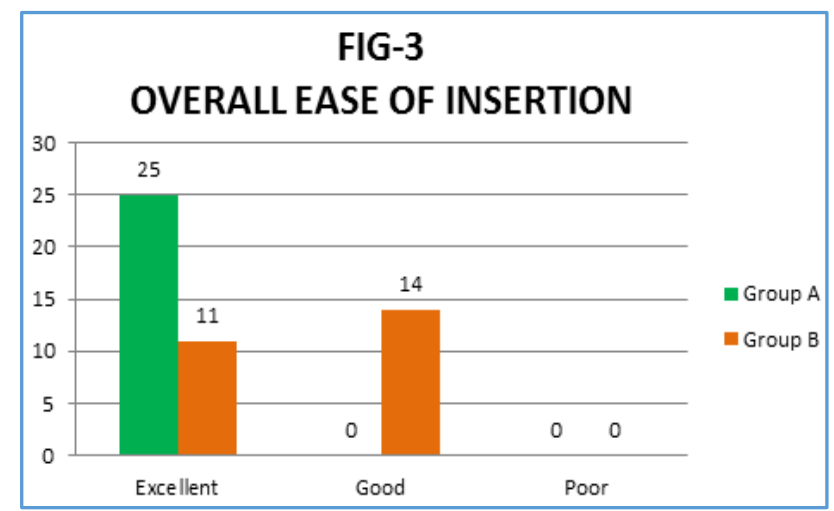

One-Sample Statistics

\begin{tabular}{|c|c|c|c|c|}
\hline & $\mathbf{N}$ & Mean & Std. Deviation & Std. Error Mean \\
\hline Excellent & 3 & 14.67 & 9.074 & 5.239 \\
\hline Good & 3 & 10.33 & 9.074 & 5.239 \\
\hline Poor & 3 & .00 & $.000(\mathrm{a})$ & .000 \\
\hline \multicolumn{5}{|c|}{ Table 6 }
\end{tabular}

Mean cannot be computed because the standard deviation is 0 .

\section{One-Sample Test}

\begin{tabular}{|c|c|c|c|c|c|c|}
\hline & \multicolumn{6}{|c|}{ Test Value $=0$} \\
\hline & \multirow{2}{*}{$\mathbf{t}$} & \multirow{2}{*}{ Df } & \multirow{2}{*}{ Sig (2-tailed) } & \multirow{2}{*}{ Mean Difference } & \multicolumn{2}{|c|}{ 95\% Confidence Interval of the Difference } \\
\hline & & & & & Lower & Upper \\
\hline Excellent & 2.800 & 2 & .107 & 14.667 & -7.87 & 37.21 \\
\hline Good & 1.972 & 2 & .187 & 10.333 & -12.21 & 32.87 \\
\hline \multicolumn{7}{|c|}{ Table 7} \\
\hline
\end{tabular}

The overall insertion conditions are excellent in Group A (Propofol with Midazolam) compared to the other groups and this is statistically significant as shown above.

\section{Number of Attempts for Successful Insertion of LMA}

In $100 \%$ of patients in group A, LMA was inserted in the first attempt, while in only $64 \%$ of patients in group B respectively. This is represented as the following data. See Fig. 4 \& Table 8.

\begin{tabular}{|c|c|c|}
\hline Attempt & Group A & Group B \\
\hline First Attempt & 25 & 16 \\
\hline Second Attempt & 0 & 9 \\
\hline \multicolumn{3}{|c|}{ Table 8 } \\
\hline
\end{tabular}

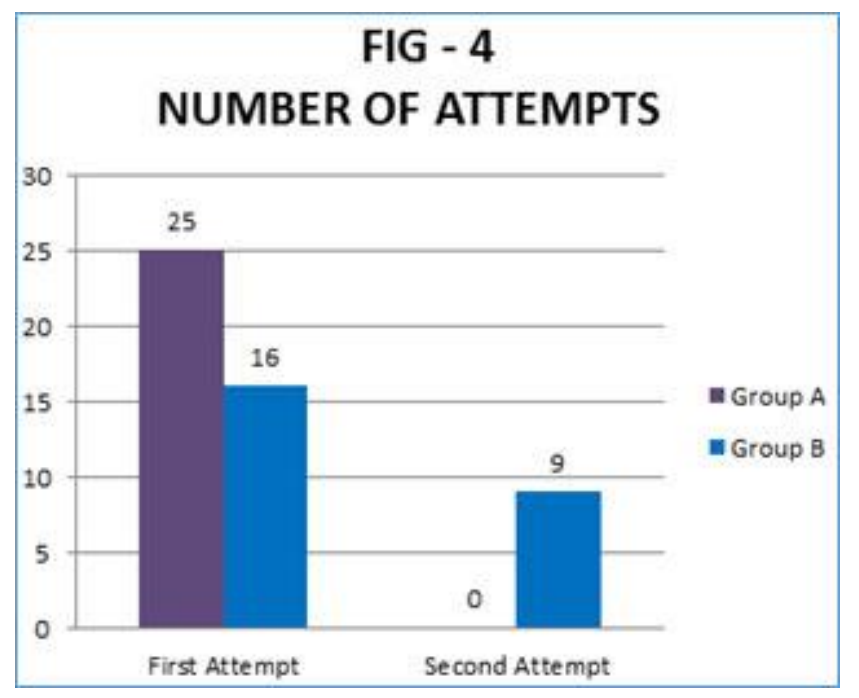

One-Sample Statistics

\begin{tabular}{|c|c|c|c|c|}
\hline & N & Mean & $\begin{array}{c}\text { Std. } \\
\text { Deviation }\end{array}$ & $\begin{array}{c}\text { Std. Error } \\
\text { Mean }\end{array}$ \\
\hline First Attempt & 3 & 17.00 & 7.550 & 4.359 \\
\hline $\begin{array}{c}\text { Second } \\
\text { Attempt }\end{array}$ & 3 & 8.00 & 7.550 & 4.359 \\
\hline \multicolumn{4}{|c|}{ Table 9 } \\
\hline
\end{tabular}

One-Sample Test

\begin{tabular}{|c|c|c|c|c|c|c|}
\hline & \multicolumn{7}{|c|}{ Test Value =0 } \\
\cline { 2 - 7 } & $\mathbf{t}$ & $\mathbf{D f}$ & $\begin{array}{c}\text { Sig } \\
\mathbf{2 -} \\
\text { tailed) }\end{array}$ & $\begin{array}{c}\text { Mean } \\
\text { Difference }\end{array}$ & $\begin{array}{c}\text { 95\% Confidence } \\
\text { Interval } \\
\text { of the Difference }\end{array}$ \\
\cline { 4 - 7 } & & & Lower & Upper \\
\hline $\begin{array}{c}\text { First } \\
\text { Attempt }\end{array}$ & 3.900 & 2 & .060 & 17.000 & -1.75 & 35.75 \\
\hline $\begin{array}{c}\text { Second } \\
\text { Attempt }\end{array}$ & 1.835 & 2 & .208 & 8.000 & -10.75 & 26.75 \\
\hline \multicolumn{7}{|c|}{ Table 10 } \\
\hline
\end{tabular}

$100 \%$ of LMA insertions in Group B was done in the first attempt while only $64 \%$ of LMA insertions were done in the first attempt in Group B respectively, this is statistically significant as shown above.

\section{Comparison of Patient Response to LMA Insertion}

Patient movement, gagging, coughing, laryngospasm during LMA insertion were compared between the 2 groups. See Fig. 5.

Patient Movement

\begin{tabular}{|c|c|c|}
\hline Patient Moving & Group A & Group B \\
\hline Yes & 0 & 3 \\
\hline No & 25 & 22 \\
\hline \multicolumn{3}{|c|}{ Table 11 } \\
\hline
\end{tabular}




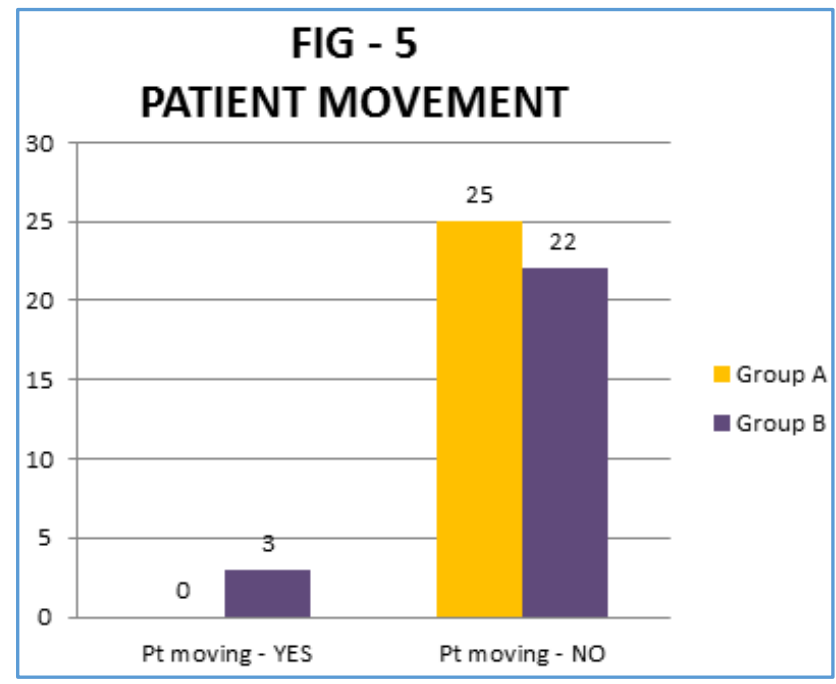

One-Sample Statistics

\begin{tabular}{|c|c|c|c|c|}
\hline & N & Mean & Std. Deviation & Std. Error Mean \\
\hline Yes & 3 & 5.00 & 6.245 & 3.606 \\
\hline No & 3 & 20.00 & 6.245 & 3.606 \\
\hline \multicolumn{5}{|c|}{ Table 12 } \\
\hline
\end{tabular}

One-Sample Test

\begin{tabular}{|c|c|c|c|c|c|c|}
\hline & \multicolumn{7}{|c|}{ Test Value =0 } \\
\cline { 3 - 7 } & & & $\begin{array}{c}\text { Sig } \\
\mathbf{2 -} \\
\text { tailed) }\end{array}$ & $\begin{array}{c}\text { Mean } \\
\text { Difference }\end{array}$ & $\begin{array}{c}\text { 95\% Confidence } \\
\text { Interval } \\
\text { of the Difference }\end{array}$ \\
\cline { 4 - 7 } & & Df & & Lower & Upper \\
\hline Yes & 1.387 & 2 & .300 & 5.000 & -10.51 & 20.51 \\
\hline No & 5.547 & 2 & .031 & 20.000 & 4.49 & 35.51 \\
\hline \multicolumn{7}{|c|}{ Table 13 } \\
\hline
\end{tabular}

There was no patient movement in all patients in group A, whereas there was movement in $12 \%$ of patients in group $B$, which is statistically very significant. Additional doses of Propofol was used for those patients.

\section{Laryngospasm}

\begin{tabular}{|c|c|c|}
\hline & Group A & Group B \\
\hline Yes & 0 & 0 \\
\hline No & 25 & 25 \\
\hline \multicolumn{2}{|c|}{ Table 14 } \\
\hline
\end{tabular}

In both the groups, there was no incidence of laryngospasm. Likewise there was no gagging or coughing in both 2 groups.

Total dose of Propofol $(\mathrm{mg} / \mathrm{kg})$ Required for LMA Insertion

\begin{tabular}{|c|c|c|}
\hline & Group A & Group B \\
\hline Total Propofol dose (mg/kg) & 2.06 & 2.60 \\
\hline \multicolumn{2}{|c|}{ Table 15 } \\
\hline \multicolumn{2}{|c|}{}
\end{tabular}

One-Sample Statistics

\begin{tabular}{|c|c|c|c|c|}
\hline & $\mathbf{N}$ & Mean & Std. Deviation & Std. Error Mean \\
\hline Does & 3 & 2.4733 & .36679 & .21177 \\
\hline \multicolumn{5}{|c|}{ Table 16 } \\
\hline
\end{tabular}

One-Sample Test

\begin{tabular}{|c|c|c|c|c|c|c|}
\hline \multirow{3}{*}{$\mathbf{t}$} & \multicolumn{9}{|c|}{ Test Value =0 } \\
\cline { 4 - 7 } & & \multirow{D}{*}{$\begin{array}{c}\text { Sig (2- } \\
\text { tailed) }\end{array}$} & $\begin{array}{c}\text { Mean } \\
\text { Difference }\end{array}$ & \multicolumn{2}{|c|}{$\begin{array}{c}\text { 95\% confidence } \\
\text { Interval of the } \\
\text { Difference }\end{array}$} \\
\cline { 5 - 7 } & & & Lower & Upper \\
\hline Does & 11.680 & 2 & .007 & 2.47333 & 1.5622 & 3.3845 \\
\hline \multicolumn{7}{|c|}{ Table 17 } \\
\hline
\end{tabular}

The mean total dose of propofol used are 2.06 and 2.60 respectively in group A, B which is also statistically significant.

Airway Trauma

\begin{tabular}{|c|c|c|}
\hline & Group A & Group B \\
\hline Yes & 0 & 9 \\
\hline No & 25 & 16 \\
\hline \multicolumn{2}{|c|}{ Table 18 } \\
\hline
\end{tabular}

Also see fig. 6 \& Table 18.

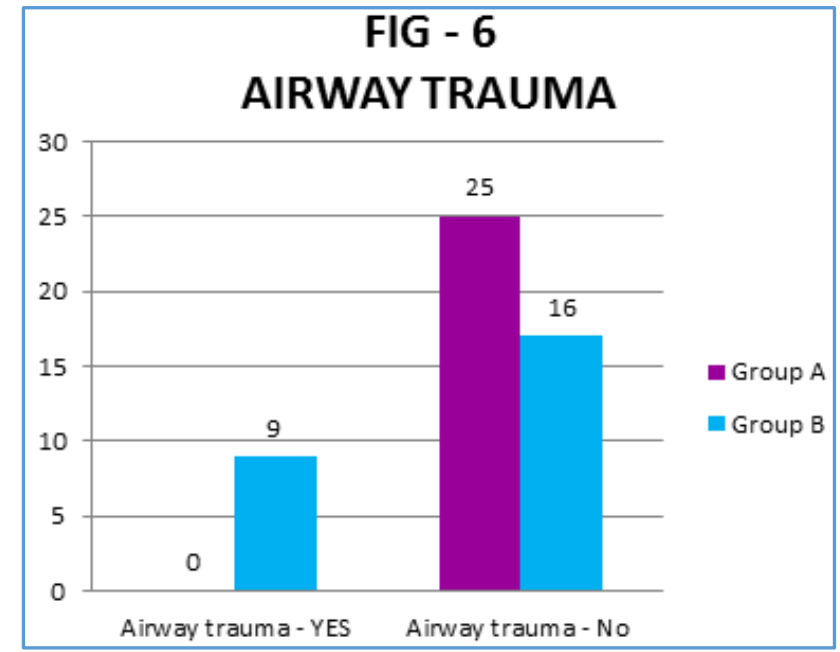

One-Sample Statistics

\begin{tabular}{|c|c|c|c|c|}
\hline $\begin{array}{c}\text { Airway } \\
\text { Trauma }\end{array}$ & N & Mean & $\begin{array}{c}\text { Std. } \\
\text { Deviation }\end{array}$ & $\begin{array}{c}\text { Std. Error } \\
\text { Mean }\end{array}$ \\
\hline Yes & 3 & 5.67 & 4.933 & 2.848 \\
\hline No & 3 & 19.33 & 4.933 & 2.848 \\
\hline \multicolumn{5}{|c|}{ Table 19 } \\
\hline
\end{tabular}

One-Sample Test

\begin{tabular}{|c|c|c|c|c|c|c|}
\hline \multirow{3}{*}{$\begin{array}{c}\text { Airway } \\
\text { Trauma }\end{array}$} & \multicolumn{7}{|c|}{ Test Value =0 } \\
\cline { 4 - 7 } & T & Df & $\begin{array}{c}\text { Sig } \\
\text { (2-tailed) }\end{array}$ & $\begin{array}{c}\text { Mean } \\
\text { Difference }\end{array}$ & $\begin{array}{c}\text { 95\% Confidence } \\
\text { Interval } \\
\text { of the Difference }\end{array}$ \\
\cline { 4 - 7 } & & & .185 & 5.667 & -6.59 & 17.92 \\
\hline Yes & 1.990 & 2 & .185 & Upper \\
\hline T No & 6.788 & 2 & .021 & 19.333 & 7.08 & 31.59 \\
\hline \multicolumn{7}{|c|}{ Table 20 } \\
\hline
\end{tabular}

The incidence of airway trauma as witnessed by blood staining of LMA is 32\% in group B, while none of group A had any, which is statistically significant.

\section{Haemodynamic Changes - Pulse Rate and MAP}

The mean variability in heart rate (heart rate pre-op minus heart rate 1 min. post-insertion) is least in group A which is statistically significant. The pictorial representation of the 
mean variability in heart rate (pre-op heart rate minus $1 \mathrm{~min}$ post-insertion heart rate) is as follows.

\section{Also see Fig. 7 \& 8.}

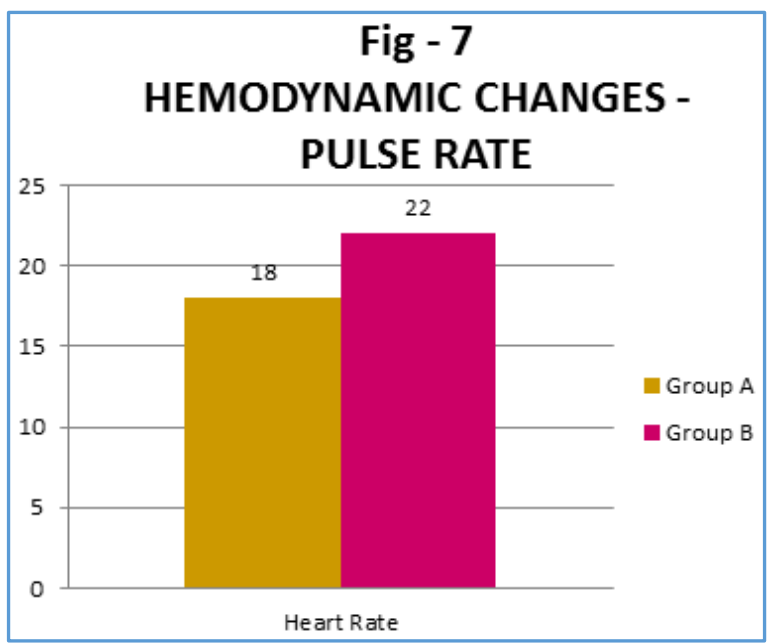

\section{One-Sample Test}

\begin{tabular}{|c|c|c|c|c|}
\hline & N & Mean & Std. Deviation & Std. Error Mean \\
\hline HR & 3 & 19.28 & 2.383 & 1.376 \\
\hline \multicolumn{5}{|c|}{ Table 21 } \\
\hline
\end{tabular}

\section{One-Sample Test}

\begin{tabular}{|c|c|c|c|c|c|c|}
\hline \multirow{2}{*}{} & \multicolumn{9}{|c|}{ Test Value =0 } \\
\cline { 3 - 7 } & $\mathbf{t}$ & $\mathbf{D f}$ & $\begin{array}{c}\text { Sig } \\
\mathbf{2}- \\
\text { tailed) }\end{array}$ & $\begin{array}{c}\text { Mean } \\
\text { Difference }\end{array}$ & \multicolumn{2}{c|}{$\begin{array}{c}\text { 95\% Confidence } \\
\text { Interval } \\
\text { of the Difference }\end{array}$} \\
\cline { 3 - 7 } & & & Lower & Upper \\
\hline HR & 14.014 & 2 & .005 & 19.280 & 13.36 & 25.20 \\
\hline \multicolumn{6}{|c|}{ Table 22 } \\
\hline
\end{tabular}

The mean variability in mean arterial pressure (pre-op MAP minus 1 min. post-insertion MAP) is least in case of group A patients than group B, which is statistically significant. There is no change in saturation (SpO2) levels either preop, post-induction or post-insertion between the 2 groups.

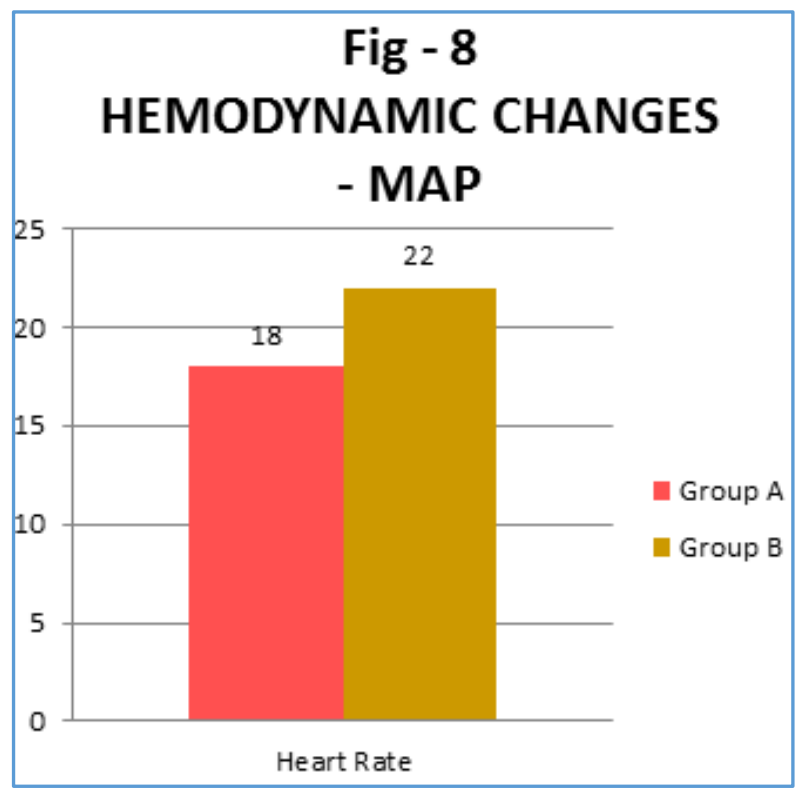

One-Sample Statistics

\begin{tabular}{|c|c|c|c|c|}
\hline & $\mathbf{N}$ & Mean & Std. Deviation & Std. Error Mean \\
\hline MAP & 3 & 21.28 & 1.698 & .980 \\
\hline \multicolumn{5}{|c|}{ Table 23 } \\
\hline
\end{tabular}

One-Sample Test

\begin{tabular}{|c|c|c|c|c|c|c|}
\hline & \multicolumn{5}{|c|}{ Test Value $=0$} \\
\cline { 2 - 6 } & \multirow{2}{*}{ T } & Df & $\begin{array}{c}\text { Sig (2- } \\
\text { tailed) }\end{array}$ & $\begin{array}{c}\text { Mean } \\
\text { Difference }\end{array}$ & $\begin{array}{c}\mathbf{9 5 \%} \\
\text { Confidence } \\
\text { Interval of the } \\
\text { Difference }\end{array}$ \\
\cline { 3 - 7 } & & & Lower & Upper \\
\hline MAP & 21.713 & 2 & .002 & 21.280 & 17.06 & 25.50 \\
\hline \multicolumn{7}{|c|}{ Table 24 } \\
\hline
\end{tabular}

\section{Summary}

In this study, the conditions of LMA insertion, patient's response to LMA insertion and the haemodynamic changes during and after LMA insertion in the following two groups of patients were observed.

Group A - Inj. Propofol $2.5 \mathrm{mg} / \mathrm{kg}+0.04 \mathrm{mg} / \mathrm{kg}$ midazolam. Group B - Inj. Propofol $2.5 \mathrm{mg} / \mathrm{kg}+0.1 \mathrm{mg} / \mathrm{kg}$ succinylcholine.

- The jaw relaxation was adequate in $100 \%$ of group A patients compared to $64 \%$ of patients in Group B.

- Overall insertion conditions were excellent in $100 \%$ of patients in group A compared to $64 \%$ of patients in group B.

- LMA was inserted successfully in the first attempt in $100 \%$ of patients in Group A compared to $64 \%$ in group B.

- Airway trauma as evidenced by blood staining of LMA was found in $32 \%$ in group B while none of the patients in Group A had airway trauma.

- Post-op myalgia was present in $40 \%$ of patients in group B.

- Patient's movement were present in $12 \%$ of patients in Group B and 0 in Group A.

- The total dose of Propofol required for successful insertion of LMA was $2.60 \mathrm{mg} / \mathrm{kg}$ in Group B, while it is $2.06 \mathrm{mg} / \mathrm{kg}$ the least in group A which is the cause of significant haemodynamic stability in patients of group $\mathrm{A}$.

\section{DISCUSSION}

Adverse response to insertion of laryngeal mask airway such as gagging, coughing and laryngospasm, may make correct positioning difficult or even impossible. So LMA insertion requires suppression of upper airway reflexes. Although propofol obtunds the upper airway reflexes, Stonham, Bree and Sneyd reported that easy insertion of the LMA was seen in only approximately $60 \%$ of patients with Propofol anaesthesia, ${ }^{17}$ which means that the sole use of Propofol does not always guarantee successful insertion of LMA, comparisons have been made between various muscles relaxants in the LMA insertion.

Cook TM, Seavel et al compared topical and intravenous lignocaine to insertion of LMA with thiopentone. 18 The group who had lignocaine topical had a lower incidence of laryngospasm. In the present study, there was no incidence of laryngospasm in both the groups.

Wafaa Taha Salem, Dept. of Anaesthesiology, National Cancer Institute, Cairo University investigated the use of 
Midazolam or mini dose succinylcholine as a co-induction agent with propofol to facilitate LMA insertion in 60 patients undergoing urological procedures. The patients were divided into 3 groups; Propofol group (P) receiving $2.5 \mathrm{mg} / \mathrm{kg}$ Propofol for Induction, while group PM received $0.04 \mathrm{mg} / \mathrm{kg}$ Midazolam 3 min. pre-induction and group PS received 0.1 $\mathrm{mg} / \mathrm{kg}$ succinylcholine $30 \mathrm{sec}$. after propofol. The number of insertion attempts, total dose of propofol, jaw relaxation, gagging, coughing, patient movement, laryngospasm, overall insertion conditions and haemodynamic changes were recorded. Significant reduction in induction dose of propofol was noted in PM groups (40\%). Success rate of first attempt was $60 \%, 95 \%$ and $90 \%$ in P, PM, PS groups respectively. Group PM showed less Haemodynamic change, overall insertion conditions were excellent in $20 \%, 75 \%$ and $50 \%$ respectively in three groups. In our study also total dose of propofol was low by $25 \%$ in group $A$, the ease of insertion and jaw relaxation was graded excellent in $100 \%$ of patients in group A. In our study also haemodynamics were stable in group A. Hence, it is concluded that midazolam aids LMA insertion in propofol anaesthesia.

\section{CONCLUSION}

To conclude, addition of Midazolam $(0.04 \mathrm{mg} / \mathrm{kg})$ to the standard dose of propofol provides better LMA insertion conditions than the addition of mini dose Succinylcholine $(0.1$ $\mathrm{mg} / \mathrm{kg}$ ).

\section{REFERENCES}

1. Brain AI. Laryngeal mask - a new concept in airway management. Br J Anaesth 1983;55(8):801-4.

2. Pennant $\mathrm{JH}$, White PF. The laryngeal mask airway. Its uses in anaesthesiology. Anaesthesiology 1993;79(1):144-63.

3. Verghese C, Brimacombe JR. Survey of laryngeal mask airway usage in 11,190 patients: safety and efficacy for conventional and non conventional usage. Anaesth Analg 1996;82(1):129-33.

4. Scanlon P, Carey M, Power M, et al. Patient response to laryngeal mask insertion after induction of anaesthesia with propofol or thiopentone. Can J Anaesth 1993;40(9):816-8.

5. Harris CF, Murray AM, Anderson JM, et al. Effects thiopentone, etomidate and propofol on hemodynamic response to tracheal intubation. Anaesthesia 1988; (Suppl 43):32-6.
6. Boysen K, Sanchez R, Krintel JJ, et al. Induction and recovery characteristics of propofol, thiopental and etomidate. Acta anaesthesia Scand 1989;33(8):689-92.

7. Shribman AJ, Smith G, Achola KJ. Cardiovascular and catecholamine responses to laryngoscopy with and without tracheal intubation. $\mathrm{Br} \mathrm{J}$ Anaesth 1987;59(3):295-9.

8. Asai T, Morris S. The laryngeal mask airway: its features, effects and role. Can J Anaesth 1994;41(10):930-60.

9. Brimacobe J. The advantages of the LMA over the tracheal tube and facemask: meta-analysis. Can J Anaesthe 1995;42(11):1017-23.

10. Ho-Tai LM, Devitt JH, Noel AG, et al. Gasleak and gastric insufflations during controlled ventilation: face mask versus laryngeal mask airway. Can J Anaesth 1998;45(3):206-11.

11. Stoneham MD, Bree SF, Sneyd JR. Facilitation of LMA insertion. Effects of lignocaine given intravenously before induction with propofol. Anaesthesia 1995;50(5):464-6.

12. Hickey S, Cameron AF, Asbury AJ. Cardiovascular response to insertion of Brain's laryngeal mask. Anaesthesia 1990;45(8):629-33.

13. Acalovaschi I, Miclescu A, Bugov L. The effects of propofol on laryngeal reactivity and the hemodynamic response to laryngeal mask insertion. Eur J Anaesthesiology 1995;12(4):351-6.

14. Ho KM, Chui PT. The use of mini-dose suxamethonium to facilitate the insertion of a laryngeal mask airway. Anaesthesia 1999;54(7): 686-9.

15. Yoshino A, Hashimoto Y, Hirashima J, et al. Low-dose succinylcholine facilitates laryngeal mask airway insertion during thiopental anaesthesia. $\mathrm{Br} \mathrm{J}$ Anaesth 1999;83(2):279-83.

16. Chui PT, Cheam EW. The use of low dose mivacurium to facilitate insertion of the laryngeal mask airway. Anaesthesia 1998;53(5):491-5.

17. Ang S, Cheong KF, Ng TI. Alfentanil co-induction for laryngeal mask insertion. Anaesthesia Intensive Care 1999;27(2):178-8.

18. Brown GW, Patel N, Ellis FR. Comparison of propofol and increased doses of thiopentone for laryngeal mask insertion. Acta Anaesthesiol Scand 1995;39(8):1103-4. 